\title{
Spatial Variability of Selected Soil Attributes under Agricultural Land Use System in a Mountainous Watershed, Ethiopia
}

\author{
Hailu Kendie Addis ${ }^{1,2}{ }^{*}$, Andreas Klik ${ }^{2}$, Stefan Strohmeier ${ }^{3}$ \\ ${ }^{1}$ Gondar Agricultural Research Center, Gondar, Ethiopia \\ ${ }^{2}$ Institute of Hydraulics and Rural Water Management, University of Natural Resources and Life Sciences, \\ Vienna, Austria \\ ${ }^{3}$ International Center for Agricultural Research in the Dry Areas, Amman, Jordan \\ Email: ${ }^{*}$ hailukendie@gmail.com
}

Received 15 May 2015; accepted 16 June 2015; published 19 June 2015

Copyright (C) 2015 by authors and Scientific Research Publishing Inc.

This work is licensed under the Creative Commons Attribution International License (CC BY). http://creativecommons.org/licenses/by/4.0/

(c) (7) Open Access

\begin{abstract}
In the Ethiopian Highlands, research projects were often measuring soil attributes of spatially structured point data but soil variability at a watershed scale is not clearly defined. This study was conducted to assess the correlation among selected soil attributes and to illustrate the spatial pattern and dependence of neighboring observations. The $53.7 \mathrm{~km}^{2}$ study watershed was divided into a $500 \mathrm{~m}$ by $500 \mathrm{~m}$ square grid using arcgis and at the center of each grid soil samples from 0 to $25 \mathrm{~cm}$ depth were collected within 184 locations. The descriptive statistics revealed available phosphorous (AP) had the largest coefficient of variation (CV = 104) while pH was the least variable. There was a positive link between elevation and SOC whereas bulk density ( $\rho d$ ) and pH indicated an inverse relationship with elevation and SOC. The value for nugget/sill of $\rho d$, $\mathrm{pH}$ and elevation are less than $\mathbf{0 . 2 5}$, and depicts that it has strong spatial autocorrelation. The value for nugget/ sill of SOC, and TN found between 0.25 and 0.75 , and indicate that they have moderate spatial autocorrelation. With regard to AP, the value for nugget/sill is more than 0.75 , which displays a weak spatial autocorrelation. Semivariograms of $\rho \mathrm{d}, \mathrm{pH}$ and elevation were best fitted to Gaussian model whereas SOC, TN and AP were best fitted to exponential function. Generally, the study verified that soil measurements taken at the given scale through regular sampling interval were adequate to capture the spatial dependence of numerous initial soil assessments in the study watershed.
\end{abstract}

\section{Keywords}

Semivariogram, Soil Attribute, Spatial Variability, Watershed

\footnotetext{
${ }^{*}$ Corresponding author.
}

How to cite this paper: Addis, H.K., Klik, A. and Strohmeier, S. (2015) Spatial Variability of Selected Soil Attributes under Agricultural Land Use System in a Mountainous Watershed, Ethiopia. International Journal of Geosciences, 6, 605-613. 


\section{Introduction}

Research has shown that soils continually undergo development and vary in space and time as a result of the combined effects of physical, chemical, and biological processes that work at different scales and with different intensities. This variability is a direct result of soil forming factors: climate, parent material, time, geomorphology and living organisms [1]. Each factor may function independently or in combination with other factors and over a wide range of spatial scales. Spatial scales reach from the micro-environment to the watershed and further occurring at many scales, while temporal scales extent from seconds to centuries and longer. Various processes occurring over different time steps and caused by various influences form different patterns of soil variability. The spatial and temporal variability of soil attributes should be observed and quantified for a better understanding of the influence of land management practices on soil function which ultimately leads to efficient site specific farming practices [2]. An efficient site specific farming practice is currently based on information about the spatial and temporal variability of the soil and this information is useful for the farmers to make decisions with regard to planting, fertilizing and harvesting [3].

Since the early 1900's soil scientists have been aware of the spatial and temporal variability of the soil [4]-[6]. However, it was not until the late 1960's and early 1970's that soil scientists began to study soil variability in a systematic way. Soil properties vary over space and time and can be assessed using classical descriptive statistics and/or geostatistics [7]. Meanwhile, there are numerous factors such as surveying cost, accessibility, topography etc. that limit the amount of spatial data needed to describe the variability of the soil in a resolution sufficient for depicting a spatial process. However, previous studies conducted in agricultural lands documented that available phosphorous showed the highest variation while $\mathrm{pH}$ the least variable soil property [2] [8]-[12].

Geostatistics incorporate information about the geographic position of the sample points during data processing. In addition, the analysis and interpretation of spatial datasets described by semivariograms to predict the values of soil attributes at unsampled locations by interpolation techniques forms an important part of geostatistics [13]. The most indispensable part of soil information in geostatistics is that each observation relates to a particular position in time and space. Geostatistics is concerned with spatial data hence, an observed value is of little interest unless location or time of measurement or both are known and considered in the analysis [14].

In the past three decades, the application of geostatistical methods by soil researchers primarily focused on predicting spatial variability along a transect [6] [10] [15] or at fine resolution (plot-scale and/or field-scale) [16]-[18]. However, the application of classical descriptive statistics and geostatistics methods in a rugged mountainous agricultural watershed was rarely considered.

Although the level of spatial soil variability is scale dependent, assessing spatial soil variability is vital before conducting site specific crop and soil management practices [19]. Typically, spatial variability of soil depends on the specific soil studied but, such information for soil of Gumara-Maksegnit agricultural watershed is lacking and hence, need to be assessed. Considering the different studies and results obtained, the aims of this research were (1) to evaluate the correlation among various soil chemical and physical attributes and (2) to illustrate the spatial pattern and dependence of soil attributes of neighboring observations.

\section{Materials and Methods}

\subsection{Study Watershed Characteristics}

The study was conducted in April 2010 on Gumara-Maksegnit watershed which has an area of $53.7 \mathrm{~km}^{2}$ and located in the northwestern Amhara region, Ethiopia between $12^{\circ} 24^{\prime}$ and $12^{\circ} 31^{\prime}$ North and between $37^{\circ} 33^{\prime}$ and $37^{\circ} 37^{\prime}$ East (Figure 1). In the study watershed, the problem of soil fertility, water shortage, costly agricultural inputs and erosion are among a number of serious challenges, which makes small-scale rainfed agriculture a risky enterprise.

The mean annual rainfall in the watershed was about $1170 \mathrm{~mm}$ at which more than $90 \%$ of the rainfall occurs during the three month period, June to August. Meanwhile, the average daily maximum and minimum temperatures were $28.5^{\circ} \mathrm{C}$ and $13.6^{\circ} \mathrm{C}$, respectively. Diverse topography is a typical characteristic of the study watershed. The elevation of the watershed varies from $1923 \mathrm{~m}$ at the outlet to $2851 \mathrm{~m}$ in the north and the mean elevation is $2237.54 \mathrm{~m}$ above sea level, which exhibit vast topographical variations over the research site (Figure 2). Meanwhile, the majority of the study watershed (90\% of the study area) is mountainous and consists of dissected terrain with steep slopes, and the remaining $10 \%$ has an undulated topography with gentle slopes. The 


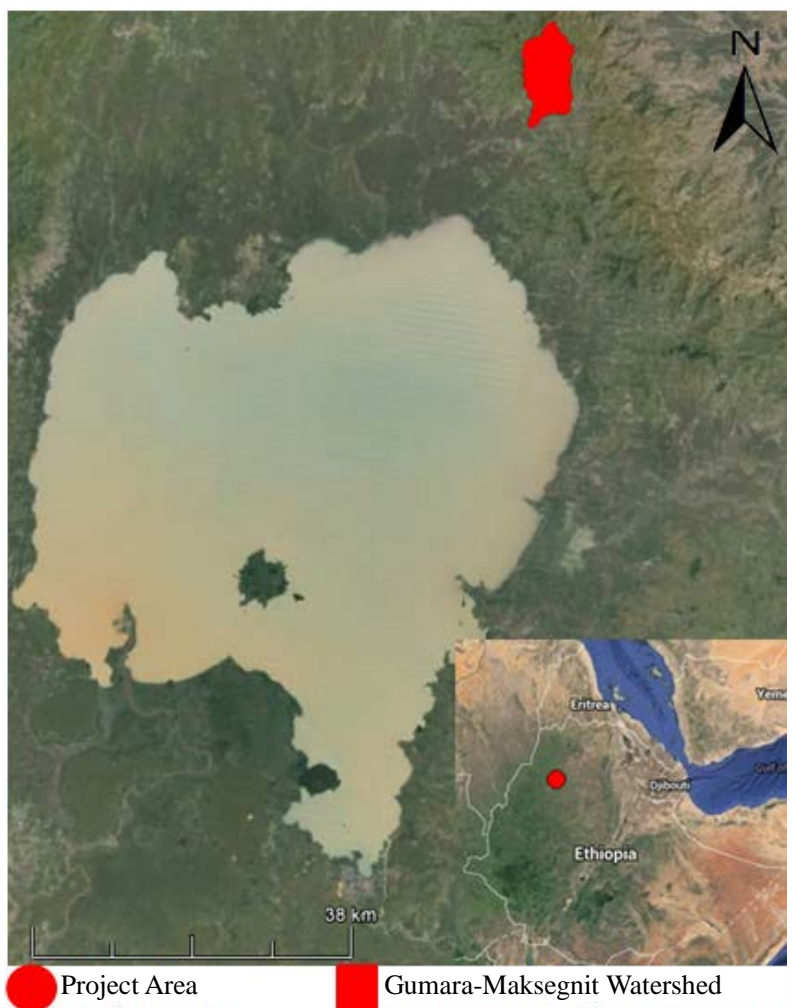

Figure 1. Overview of the project watershed area in the Northwest Amhara region, Ethiopia.

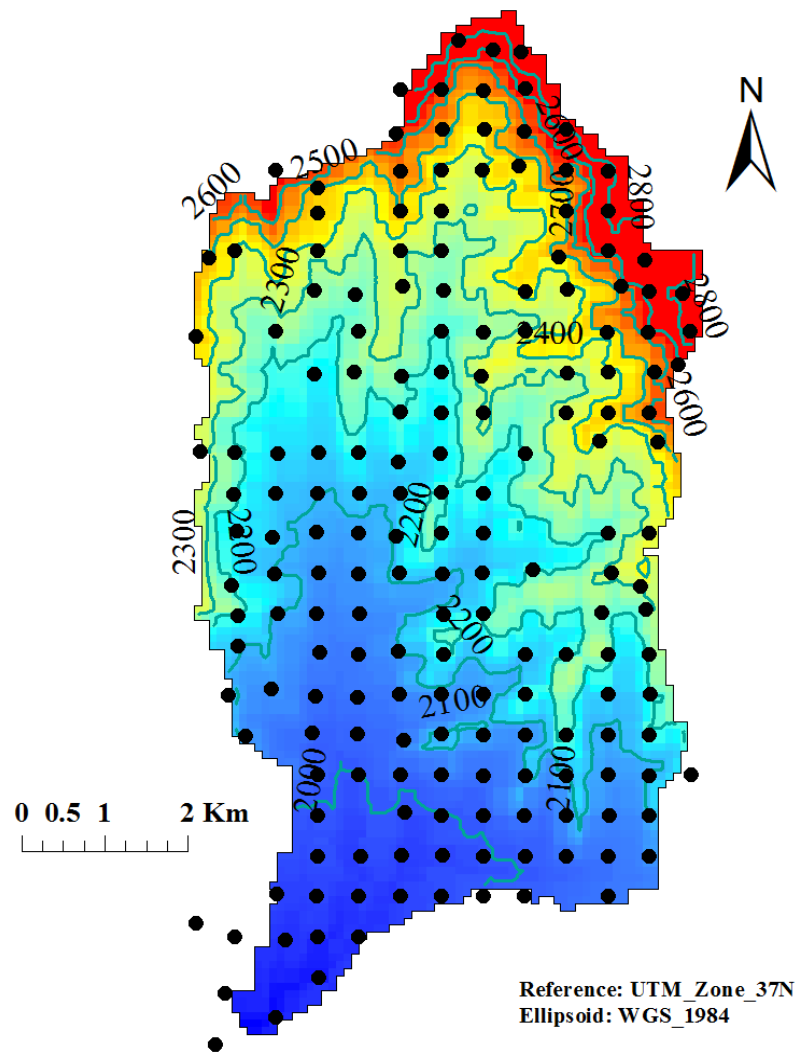

Figure 2. Contour map of the study watershed with the distribution of observed soil samples. 
slope of the study watershed ranges from nearly flat (less than $2 \%$ ) to exceptionally steep (greater than $70 \%$ ) in the northern part of the watershed and the mean watershed slope is $22.06 \%$. The study watershed was mainly covered by agricultural land (63.5\%) followed by forest (24.3\%) and grassland $12.2 \%$. The major crops grown in the agricultural land included sorghum, teff (EragrostisTeff), fava bean, lentil, wheat, chickpea, linseed, fenugreek, and barley. Eragrostis Teff and sorghum were the main staple crops, whereas chickpea was grown at residual moisture in the lower regions of the watershed where clay soil textural classes were dominant and this crop cannot grow at higher altitudes.

\subsection{Geological Characteristics}

The study area, which is part of the northern Highlands of Ethiopia, belongs to the Trapp series of Tertiary volcanic eruptions [20]. The physiographic structure of the study area is a result of its geological origin. The Highlands and mountain ridges are created by uplifting of landmasses and the mountain peaks are the results of lava emissions [20]. The geomorphic processes which took place for a long period of time had significantly reshaped the area. The soil types are predominately Cambisol and Leptosol which are found in the upper and central part of the watershed, whereas Vertisol is found in the lower catchment near the main outlet. Denkez mountain ridge is the peak part of the watershed and it is a line of demarcation that separates the two main Ethiopian basin systems (Nile and Tekezi basins).

\subsection{Soil Analyses}

The study watershed was divided into a $500 \mathrm{~m}$ by $500 \mathrm{~m}$ square grid and approximately, at the center of each grid soil samples were collected within 184 locations over a $53.7 \mathrm{~km}^{2}$ watershed using auger and core cylinder equipment. Garmin explorer GPS accuracy: $( \pm 3 \mathrm{~m})$ was used for locating soil sampling points and measuring elevation in the field. However, some sampling points were shifted a bit from the center of the grid due to difficult topographic conditions. Soil samples in the study watershed were collected during the latter part of the dry season.

At each grid center, soil samples of about $2 \mathrm{~kg}$ were removed from the surface soil horizon, which might range from $0-25 \mathrm{~cm}$ based on the surface soil depth, with the best available tool (bucket auger) for chemical and physical analysis. Undisturbed core samples from $10-15 \mathrm{~cm}$ depth were taken to determine bulk density ( $\rho d$ ) following the procedure of [21]. The $\mathrm{pH}$ value of the soil was measured with a $\mathrm{pH}$ meter in the supernatant suspension of 1:2.5 ratio (sample to water mixture)measured using glass electrode $\mathrm{pH}$ meter as described by Peech [22]. Soil organic carbon was determined by wet oxidation method as described by De Vos et al. [23]. Available Phosphorus (AP) was extracted using sodium bicarbonate solution at $\mathrm{pH} 8.5$ following the procedure described by Olsen [24]. Total nitrogen (TN) was determined using the Kjedahl method as described by Jackson and Barak [25].

\subsection{Statistical Analyses}

\subsubsection{Classical Statistics}

The physical and chemical soil data obtained in the study watershed were subject to descriptive statistics using classical statistical analyses procedures to get minimum, maximum, range, mean, median, standard deviation (sd), standard error of mean, skewness, kurtosis and coefficient of variation (CV) of soil attributes using R software [26]. When the coefficient of skewness of a variable was greater than 1 the variable was transformed using a natural logarithm to a nearly normal distribution before using geostatistical analysis [27].

\subsubsection{Semivariograms}

In the study of spatial patterns and processes, close observations are more likely to be similar than those far apart however; variations are generally highly irregular and not exactly described by deterministic equations [28]. A spatial correlation in spatially structured point data measured at sample locations can be described through the semivariogram function. For $N$ pairs of values of soil property $A_{i}$ separated by a distance $h$ [29] the semivariogram function is defined through the following equation:

$$
\gamma(h)=\frac{1}{2 N(h)} \sum_{i=1}^{N(h)}\left[A_{i}\left(x_{i}\right)-A_{i}\left(x_{i}+h\right)\right]^{2}
$$


Semivariogram functions have many different forms and shapes and all semivariograms have a zero value at the origin. Some of the semivariogram models for natural resources evaluation were comprehensively discussed by Goovaerts [29]. GS+ [30] was used to obtain the semivariogram model of each observed soil attributes. The proposed model with the least reduced sum of squares (RSS) was selected for spatial autocorrelation process. The study also followed all the procedures described by Robertson [30], for finding the best fitted semivariogram models.

\section{Results and Discussions}

\subsection{Assessing the Descriptive Statistics}

The observed data for the parameters SOC, TN, AP, pH, bulk density, and elevation were subjected to classical statistical analyses. The descriptive statistical summary for the measured soil physical and chemical properties of the study watershed is presented in Table 1. Over the sampled watershed, mean values of SOC, pH, and TN were $1.49 \% \pm 0.07 \%, 6.75 \% \pm 0.03$, and $0.21 \% \pm 0.01 \%$, respectively. The soil analyses also showed that the value of bulk density ranged mainly from $0.83\left(\mathrm{~g} \cdot \mathrm{cm}^{-3}\right)$ to $1.70\left(\mathrm{~g} \cdot \mathrm{cm}^{-3}\right)$ with the mean value of $1.28 \pm 0.01$ $\left(\mathrm{g} \cdot \mathrm{cm}^{-3}\right)$, while the mean value of AP was $14.20 \pm 1.09(\mathrm{ppm})$ (Table 1$)$. SOC, AP, TN and elevation had skewness coefficient greater than 1 , hence the natural logarithm was applies to stabilize the variance.

As a standardized measure of the variance, the coefficient of variation (CV) was used to describe the shape of a frequency distribution of the observation [28]. Based on the CV values of the observed soil attributes, AP, SOC, TN were the most variable soil properties, with CV greater than $37 \%$. Observed bulk density ( $\rho d$ ) was moderately variable, with CV between $14 \%$ - 27\%, whereas $\mathrm{pH}$ was the least variable (CV less than $7 \%$ ). The descriptive analyses also revealed that AP had the largest variation (CV equals to 104\%). Similarly, [2] documented that AP showed the highest, whereas $\mathrm{pH}$ the least $\mathrm{CV}$. In addition, previous researches also depicted low coefficients of variation for $\mathrm{pH}$ compared to the other soil properties [8] [9] [11] [12].

\subsection{The Effects of Elevation on Soil Properties}

Considering the soil attributes/elevation relationships, one might expect that the spatial pattern and magnitude of observed soil attributes should be strongly related to elevation of the watershed, since it dictates the flow direction and accumulation, drainage network, and slope gradient which eventually contributes to nutrient leaching, soil erosion and sediment deposition. Investigating the relationship of SOC with elevation is crucial as SOC is a major part of the terrestrial carbon reservoir which plays an important role in the global carbon (C) cycle [31]. In the study watershed, there was a positive linkage between elevation and SOC (Table 2). These findings were in line with that of Kidanemariam et al. [32] who reported a positive correlation between SOC and altitude. Soils of the upper catchments had the highest SOC contents and various factors may affect the link between SOC and elevation. Lower temperature and increased soil moisture probably reduce decomposition rates and thus the accumulation of SOC at upper catchment of the study watershed. Similarly, research conducted by Kirschbaum [33] showed that lower soil temperature usually decreased litter decay rates and soil organic matter decomposition rates [34]. Bulk density $(\rho d)$ and $\mathrm{pH}$ indicated an inverse $(\mathrm{p}<0.001)$ and TN a direct relationship $(\mathrm{p}<0.001)$

Table 1. Descriptive statistics summary for the selected soil attributes and elevation of the study watershed.

\begin{tabular}{|c|c|c|c|c|c|c|c|c|c|c|}
\hline Soil attributes & No. of samples & Min. & Max. & Range & Mean & Median & sd & se (mean) & Skewness & $\mathrm{CV}$ \\
\hline$\rho d\left(\mathrm{~g} \cdot \mathrm{cm}^{-3}\right)$ & 184 & 0.83 & 1.70 & 0.87 & 1.28 & 1.28 & 0.19 & 0.01 & 0.09 & 14.7 \\
\hline SOC (\%) & 184 & 0.12 & 4.65 & 4.53 & 1.49 & 1.19 & 0.99 & 0.07 & 1.03 & 66.7 \\
\hline TN (\%) & 184 & 0.03 & 0.91 & 0.88 & 0.21 & 0.20 & 0.14 & 0.01 & 2.17 & 66.7 \\
\hline $\mathrm{AP}(\mathrm{ppm})$ & 184 & 1.16 & 77.16 & 76.00 & 14.20 & 8.35 & 14.74 & 1.09 & 1.93 & 104 \\
\hline $\mathrm{pH}\left(\mathrm{H}_{2} \mathrm{O} 1 / 2.5\right)$ & 184 & 5.34 & 7.98 & 2.64 & 6.75 & 6.68 & 0.44 & 0.03 & 0.17 & 6.52 \\
\hline Elevation (m) & 184 & 1933.00 & 2852.00 & 919.00 & 2242.00 & 2160.00 & 238.11 & 17.55 & 1.01 & 10.6 \\
\hline
\end{tabular}

$\mathrm{\rho d}$ —Bulk density, SOC—Soil Organic Carbon, TN—Total Nitrogen, AP—Available Phosphorous, sd—Standard deviation, se (mean)—Standard error of mean, CV-Coefficient of Variation. 
with elevation. Meanwhile, SOC was significantly correlated with TN $(\mathrm{p}<0.001)$ and negatively correlated with bulk density and $\mathrm{pH}(\mathrm{p}<0.001)$ (Table 2$)$.

\subsection{Spatial Variability}

The resulting semivariograms exhibits the existence of diverse spatial dependence for the study watershed (Table 3). The value of relative nugget effect or nugget to sillratio $\left(\mathrm{C}_{0} / \mathrm{C}_{0}+\mathrm{C}\right)$ displays the spatial autocorrelation [35]. According to [16] the ratio of nugget to sill $\left(C_{0} / C_{0}+C\right)$ of less than $0.25,0.25$ to 0.75 , and greater than 0.75 can reflect strong, moderate and weak spatial autocorrelation, respectively. The value for relative nugget effect of bulk density, $\mathrm{pH}$ and elevation are less than 0.25 , and depicts that it has strong spatial autocorrelation. The values for relative nugget effect of SOC and TN are between 0.25 and 0.75 , and indicate that they have moderate spatial autocorrelation. With regard to AP the value for relative nugget effect is more than 0.75 , and depicts that it has weak spatial autocorrelation. Generally, all measured soil properties in the study site varied in their spatial dependence and revealed a positive nugget effect with low sampling error (Table 3).

The resulting semivariograms on different directions including $0,45,90,135$ degrees for all soil attributes showed that effective range and sill of semivariograms were uniform and there was no clear anisotropy, therefore the spatial variability for the selected soil attributes were assumed to be identical in different directions (isotropic). The semivariograms of bulk density ( $\rho \mathrm{d}), \mathrm{pH}$, and elevation were best fitted to Gaussian model while that of SOC and TN were best fitted to exponential function (Table 3). Although the semivariogram of AP seemed that it was best described by the exponential function, the resulting spatial structure clearly showed a pure nugget effect. Meanwhile, the lag distances for the observed soil attributes were much longer than the sampling interval (Table 3). Thus, the sampling design used in the study watershed for the selected soil attributes was adequately revealed spatial distribution. As an illustration, the experimental semivariograms of bulk density, elevation, SOC, TN, AP and pH for the best fitted model are displayed in Figure 3(a) to Figure 4(d), respectively.

Table 2. Correlation coefficient matrix of the selected soil attributes and elevation of the study watershed.

\begin{tabular}{|c|c|c|c|c|c|c|}
\hline Soil Property & AP (ppm) & $\rho d\left(\mathrm{~g} \cdot \mathrm{cm}^{-3}\right)$ & Elevation (m) & $\mathrm{pH}\left(\mathrm{H}_{2} \mathrm{O} 1 / 2.5\right)$ & SOC (\%) & $\mathrm{TN}(\%)$ \\
\hline $\mathrm{AP}(\mathrm{ppm})$ & - & & & & & \\
\hline$\rho d\left(\mathrm{~g} \cdot \mathrm{cm}^{-3}\right)$ & -0.11 & - & & & & \\
\hline Elevation (m) & -0.04 & $-0.46^{* * *}$ & - & & & \\
\hline $\mathrm{pH}\left(\mathrm{H}_{2} \mathrm{O} 1 / 2.5\right)$ & -0.02 & $0.49^{* * * *}$ & $-0.60^{* * * *}$ & - & & \\
\hline SOC (\%) & 0.13 & $-0.33^{* * * *}$ & $0.41^{* * * *}$ & $-0.39^{* * * *}$ & - & \\
\hline $\mathrm{TN}(\%)$ & $0.26^{* *}$ & $-0.28^{* *}$ & $0.25^{* *}$ & $-0.40^{* * *}$ & $0.42^{* * * *}$ & - \\
\hline
\end{tabular}

Asterisks indicate correlation coefficient is significant at ${ }^{*} \mathrm{p}<0.05 ;{ }^{* *} \mathrm{p}<0.01 ;{ }^{* * *} \mathrm{p}<0.001$ (two-sided).

Table 3. The semivariogram parameters corresponding to the selected model of some soil attributes and elevation of the study watershed.

\begin{tabular}{cccccccc}
\hline Variable & Model type & Nugget [Co] & Sill $[\mathbf{C o}+\mathbf{C}]$ & Range Ao $(\mathbf{m})$ & RSS & $\mathbf{r}^{2}$ & RNE $[\mathbf{C o} /(\mathbf{C o}+\mathbf{C})]$ \\
\hline $\mathrm{\rho d}\left(\mathrm{g} \cdot \mathrm{cm}^{-3}\right)$ & Gaussian & 0.0209 & 0.1195 & 12110 & $1.14 \mathrm{E}-05$ & 0.978 & 0.17 \\
$\mathrm{SOC}(\%)$ & Exponential & 0.395 & 0.791 & 9530 & $2.01 \mathrm{E}-03$ & 0.942 & 0.50 \\
$\mathrm{TN}(\%)$ & Exponential & 0.234 & 0.736 & 12230 & $2.56 \mathrm{E}-03$ & 0.935 & 0.32 \\
$\mathrm{AP}(\mathrm{ppm})$ & Exponential & 0.89 & 1.78 & 21100.00 & 0.0172 & 0.64 & 0.50 \\
$\mathrm{pH}\left(\mathrm{H}_{2} \mathrm{O} 1 / 2.5\right)$ & Gaussian & 0.113 & 0.553 & 16460 & $1.13 \mathrm{E}-03$ & 0.892 & 0.20 \\
Elevation (m) & Gaussian & 0.0006 & 0.0636 & 12210 & $1.51 \mathrm{E}-06$ & 0.993 & 0.01 \\
\hline
\end{tabular}

RSS—Residual Sum of Squares, $\mathrm{r}^{2}$ —Coefficient of determination, RNE—Relative nugget effect. 


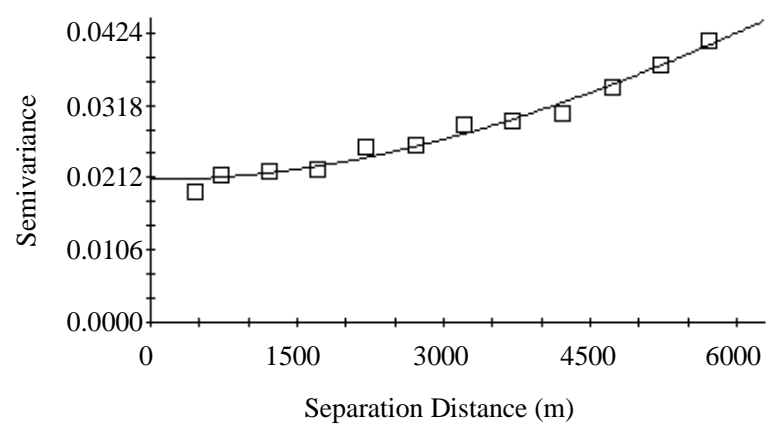

(a)

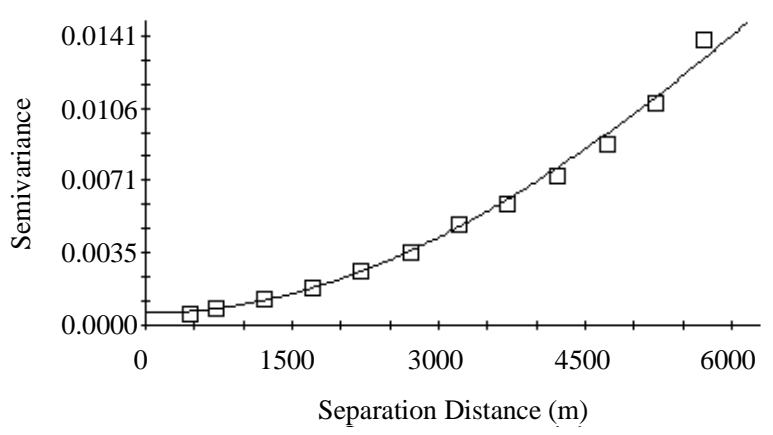

(b)

Figure 3. Semivariogram of (a) Bulk density in $\mathrm{g} / \mathrm{cm}^{3}$ and (b) Elevation in $\mathrm{m}$ of the study watershed.

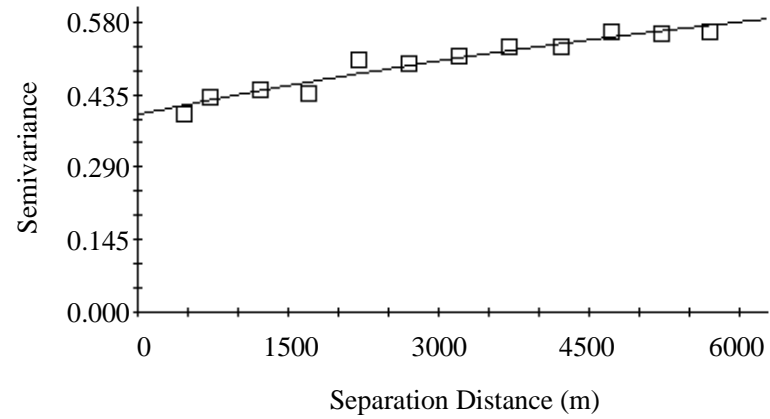

(a)

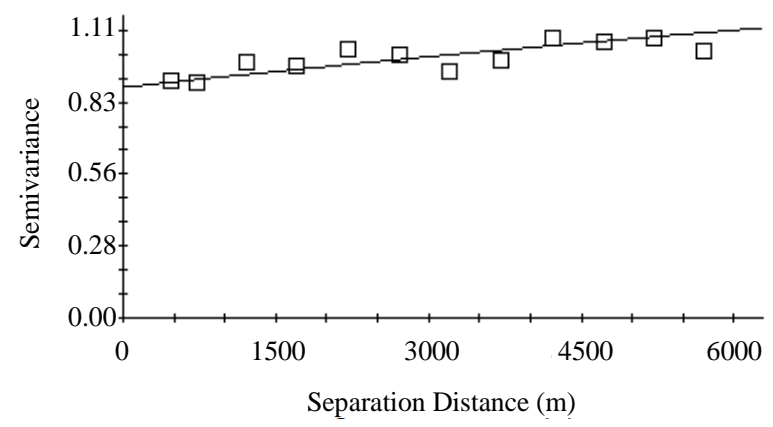

(c)

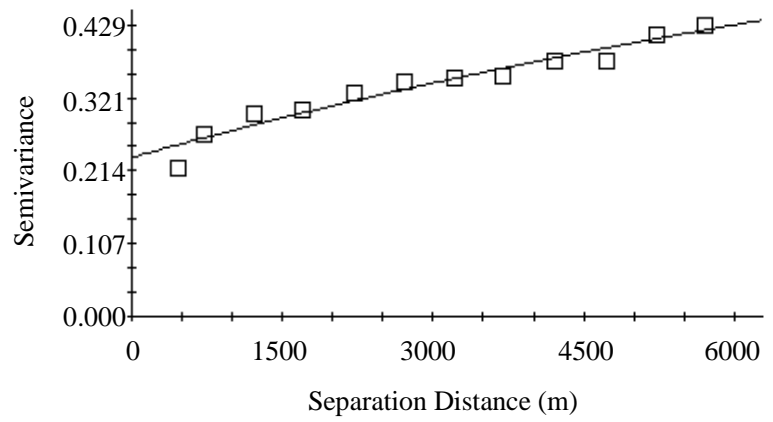

(b)

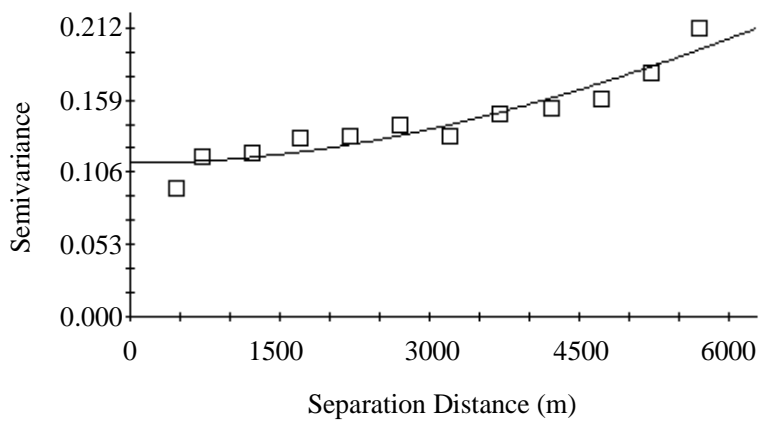

(d)

Figure 4. Semivariogram of soil chemical properties of the study watershed (a) SOC \%, (b) TN \%, (c) AP (ppm) and (d) pH.

\section{Conclusions}

The spatial variation of the selected soil attributes sampled from 0 to $25 \mathrm{~cm}$ depth of the surface horizon in a rugged mountainous agricultural watershed was explored and assessed using classical and geostatistical methods. The descriptive statistics revealed that AP had the largest coefficient of variation while $\mathrm{pH}$ was the least variable. The correlation analysis indicated that bulk density ( $\rho \mathrm{d})$ was significantly positively correlated with $\mathrm{pH}$ while, negatively correlated with SOC and elevation. Considering the soil attributes/elevation relationships, the study showed that the magnitudes of observed soil attributes were strongly linked to elevation of the watershed. SOC and TN were moderately spatially dependent with the ratio of nugget to sill $\left(\mathrm{C}_{0} / \mathrm{C}_{0}+\mathrm{C}\right)$ found between 0.25 and 0.75 , whereas $\mathrm{pH}$, bulk density and elevation were exhibited strongly spatially dependent with the ratio of nugget to sill less than 0.25 . AP had weak spatial autocorrelation, and the value for nugget/sill is more than 0.75 . The semivariograms of SOC and TN were best fitted to the exponential function while bulk density, $\mathrm{pH}$ and elevation were best fitted to the Gaussian model. In general, this study had verified that soil measurements taken at the given scale through regular sampling interval were adequate for determining the spatial dependence of numerous initial soil assessments across the different elevations of the study watershed. It could, therefore, be 
recommended that further study in spatial soil variability at a watershed scale should focus on method(s) of determining the spatial pattern and spatial dependence of the soil attributes.

\section{Acknowledgements}

This study was carried out within the cooperative project "Unlocking the potential of rainfed agriculture in Ethiopia for improved rural livelihoods" coordinated by the International Center of Agriculture Research in the Dry Areas (ICARDA), Boku University of Natural Resources and Life Sciences, Vienna and Amhara Regional Agricultural Research Institute (ARARI), and financed by Austrian Development Agency (ADA). We would like to thank the staff of Gondar Agricultural Research Center, Soil and Water Management Research Directorate, for providing experimental data. The authors would also thank Prof. Ole Wendroth from Kentucky University, for editing the manuscript and providing substantial comments and suggestions.

\section{References}

[1] Jenny, H. (1994) Factors of Soil Formation: A System of Quantitative Pedology. Courier Corporation, Chelmsford.

[2] Sun, B., Zhou, S. and Zhao, Q. (2003) Evaluation of Spatial and Temporal Changes of Soil Quality Based on Geostatistical Analysis in the Hill Region of Subtropical China. Geoderma, 115, 85-99. http://dx.doi.org/10.1016/S0016-7061(03)00078-8

[3] Khosla, R. (2010) Precision Agriculture: Challenges and Opportunities in a Flat World. 19th World Congress of Soil Science, Soil Solutions for a Changing World, Brisbane, 1-6 August 2010, $26-28$.

[4] Nielsen, D.R., Biggar, J.W. and Erh, K.T. (1973) Spatial Variability of Field-Measured Soil-Water Properties. University of California, Division of Agricultural Sciences, Oakland.

[5] Smith, H.F. (1938) An Empirical Law Describing Heterogeneity in the Yields of Agricultural Crops. The Journal of Agricultural Science, 28, 1-23. http://dx.doi.org/10.1017/S0021859600050516

[6] Webster, R. and Cuanalo, H.E. (1975) Soil Transect Correlograms of North Oxfordshire and Their Interpretation. Journal of Soil Science, 26, 176-194. http://dx.doi.org/10.1111/j.1365-2389.1975.tb01942.x

[7] Jabro, J.D., Stevens, W.B., Evans, R.G. and Iversen, W.M. (2010) Spatial Variability and Correlation of Selected Soil Properties in the AP Horizon of a CRP Grassland. Applied Engineering in Agriculture, 26, 419-428. http://dx.doi.org/10.13031/2013.29957

[8] Abu, S.T. and Malgwi, W.B. (2011) Spatial Variability of Soil Physico-Chemical Properties in Kadawa Irrigation Project in Sudan Savanna Agroecology of Nigeria. International Journal of Agricultural Research, 6, 714-735. http://dx.doi.org/10.3923/ijar.2011.714.735

[9] Aimrun, W., Amin, M.S.M., Ahmad, D., Hanafi, M.M. and Chan, C.S. (2007) Spatial Variability of Bulk Soil Electrical Conductivity in a Malaysian Paddy Field: Key to Soil Management. Paddy and Water Environment, 5, 113-121. http://dx.doi.org/10.1007/s10333-007-0072-z

[10] Schloeder, C.A., Zimmerman, N.E. and Jacobs, M.J. (2001) Comparison of Methods for Interpolating Soil Properties Using Limited Data. Soil Sciences Society of America Journal, 65, 470-479. http://dx.doi.org/10.2136/sssaj2001.652470x

[11] Tsegaye, T. and Hill, R.L. (1998) Intensive Tillage Effects on Spatial Variability of Soil Test, Plant Growth, and Nutrient Uptake Measurements. Soil Science, 163, 155-165. http://dx.doi.org/10.1097/00010694-199802000-00009

[12] Yost, R.S., Uehara, G. and Fox, R.L. (1982) Geostatistical Analysis of Soil Chemical Properties of Large Land Areas. I. Semi-Variograms. Soil Science Society of America Journal, 46, 1028-1032. http://dx.doi.org/10.2136/sssaj1982.03615995004600050028x

[13] Vieira, S.R., Hatfield, J.L., Nielsen, D.R. and Biggar, J.W. (1983) Geostatistical Theory and Application to Variability of Some Agronomical Properties. University of California, Division of Agricultural Sciences, Oakland.

[14] Goovaerts, P. (1999) Geostatistics in Soil Science: State-of-the-Art and Perspectives. Geoderma, 89, 1-45. http://dx.doi.org/10.1016/S0016-7061(98)00078-0

[15] Voltz, M. and Webster, R. (1990) A Comparison of Kriging, Cubic Splines and Classification for Predicting Soil Properties from Sample Information. Journal of Soil Science, 41, 473-490. http://dx.doi.org/10.1111/j.1365-2389.1990.tb00080.x

[16] Cambardella, C.A., Moorman, T.B., Parkin, T.B., Karlen, D.L., Novak, J.M., Turco, R.F. and Konopka, A.E. (1994) Field-Scale Variability of Soil Properties in Central Iowa Soils. Soil Science Society of America Journal, 58, 15011511. http://dx.doi.org/10.2136/sssaj1994.03615995005800050033x 
[17] Cassel, D.K., Wendroth, O. and Nielsen, D.R. (2000) Assessing Spatial Variability in an Agricultural Experiment Station Field: Opportunities Arising from Spatial Dependence. Agronomy Journal, 92, 706-714. http://dx.doi.org/10.2134/agronj2000.924706x

[18] Stenger, R., Priesack, E. and Beese, F. (2002) Spatial Variation of Nitrate-N and Related Soil Properties at the PlotScale. Geoderma, 105, 259-275. http://dx.doi.org/10.1016/S0016-7061(01)00107-0

[19] Worsham, L., Markewitz, D. and Nibbelink, N. (2010) Incorporating Spatial Dependence into Estimates of Soil Carbon Contents under Different Land Covers. Soil Science Society of America Journal, 74, 635-646. http://dx.doi.org/10.2136/sssaj2008.0412

[20] Mohr, P.A. (1963) The Geology of Ethiopia. Vol. 1, University College of Addis Ababa Press, Addis Ababa.

[21] Smith, K.A., Mullins, C.E., et al. (1991) Soil Analysis: Physical Methods. Marcel Dekker, Inc., New York.

[22] Peech, M. (1965) Hydrogen Ion Activity. In: Black, C.A., et al., Eds., Methods of Soil Analysis, Part 2, American Society of Agronomy, Madison, 914-926.

[23] De Vos, B., Lettens, S., Muys, B. and Deckers, J.A. (2007) Walkley-Black Analysis of Forest Soil Organic Carbon: Recovery, Limitations and Uncertainty. Soil Use and Management, 23, 221-229. http://dx.doi.org/10.1111/j.1475-2743.2007.00084.x

[24] Olsen, S.R. (1954) Estimation of Available Phosphorus in Soils by Extraction with Sodium Bicarbonate.

[25] Jackson, M.L. and Barak, P. (2005) Soil Chemical Analysis: Advanced Course. Parallel Press, Madison.

[26] R Development Core Team (2013) R: A Language and Environment for Statistical Computing. R Foundation for Statistical Computing, Vienna. http://www.R-project.org

[27] Webster, R. and Oliver, M.A. (2001) Geostatistics for Environmental Scientists (Statistics in Practice). John Wiley \& Sons, Brisbane, Australia.

[28] Nielsen, D.R. and Wendroth, O. (2003) Spatial and Temporal Statistics: Sampling Field Soils and Their Vegetation. Catena Verlag, Reiskirchen. Geoscience Publisher, Germany.

[29] Goovaerts, P. (1997) Geostatistics for Natural Resources Evaluation. Oxford University Press, New York, 512 p.

[30] Robertson, G.P. (2008) GS+: Geostatistics for the Environmental Sciences. Gamma Design Software, Plainwell.

[31] Xu, G.C., Li, Z.B., Li, P., Lu, K.X. and Wang, Y. (2013) Spatial Variability of Soil Organic Carbon in a Typical Watershed in the Source Area of the Middle Dan River, China. Soil Research, 51, 41-49. http://dx.doi.org/10.1071/SR12327

[32] Kidanemariam, A., Gebrekidan, H., Mamo, T., Kibret, K., et al. (2012) Impact of Altitude and Land Use Type on Some Physical and Chemical Properties of Acidic Soils in Tsegede Highlands, Northern Ethiopia. Open Journal of Soil Science, 2, 223-233. http://dx.doi.org/10.4236/ojss.2012.23027

[33] Kirschbaum, M.U. (1995) The Temperature Dependence of Soil Organic Matter Decomposition, and the Effect of Global Warming on Soil Organic C Storage. Soil Biology and Biochemistry, 27, 753-760. http://dx.doi.org/10.1016/0038-0717(94)00242-S

[34] Rustad, L.E. and Fernandez, I.J. (1998) Experimental Soil Warming Effects on $\mathrm{CO}_{2}$ and $\mathrm{CH}_{4}$ Flux from a Low Elevation Spruce-Fir Forest Soil in Maine, USA. Global Change Biology, 4, 597-605. http://dx.doi.org/10.1046/j.1365-2486.1998.00169.x

[35] Li, H. and Reynolds, J.F. (1995) On Definition and Quantification of Heterogeneity. Oikos, 73, 280-284. http://dx.doi.org/10.2307/3545921 